\title{
Network theory of stakeholder influences: a revisited approach
}

\author{
FABRICIO STOCKER ${ }^{1}$ \\ Keysa Manuela Cunha Mascena ${ }^{2}$ \\ ANa Cláudia AZeVEdo ${ }^{1}$ \\ JoÃo MaURícIo Gama BoAVENTURA ${ }^{1}$
}

${ }^{1}$ Universidade de SÃo Paulo (USP) / FACUldade de ECONOMIA, AdMINISTRAÇÃo E CONTABILIDAde, SÃo PAULO - SP, BRAZIL ${ }^{2}$ UNIVERSIDADE DE FORTALEZA (UNIFOR), FORTALEZA - CE, BRAZIL

\begin{abstract}
The interactions among multiple stakeholders have gained importance in the last decades, given the speed with which information is spread and connections are established between individuals and groups. However, there is still a research gap, which is the lack of consolidation of the empirical studies that analyzed the phenomenon of stakeholder networks and their contribution to the advancement of the theory. Thus, this work aims to investigate the evolution of the stakeholder networks approach in the last 20 years, that is, to revisit Rowley's theory (1997) and to bring a panorama of its evolution to the present day. This essay is based on two research scopes: Network Theories- society in networks and interoganizational networks and Theory of Stakeholders, integrated in the composition of Rowley's proposal (1997)- Network Theory of Stakeholders Influences. From a sociometric analysis and systematic review of 228 articles collected in the Web of Science between 1997 and 2017, it was possible to analyze the evolution of this approach. Based on this reflection, it is possible to infer that recent research shifts the focus of the relations with the stakeholders, centered in the organization, to those of a decentralized network with several actors. In addition, there is a trend of studies of networks formed by groups of stakeholders and the social identities of individuals members of these groups. The contribution of this study consists of presenting an overview of the Theory of Stakeholder Networks analyzing reference networks, theoretical and empirical contributions, trends and research agenda for the theme, which will help in the development of future work.
\end{abstract}

Keywords: Multiple Stakeholders. Interorganizational Networks. Stakeholder theory. Influence of stakeholders. Sociometric analysis.

\section{Teoria de Redes de Influências de Stakeholders: uma abordagem revisitada}

\section{Resumo}

As interações entre múltiplos stakeholders vêm ganhando importância nas últimas décadas, dada a velocidade com que se propagam informações e se estabelecem conexões entre indivíduos e grupos. Porém, a pesquisa sobre o tema ainda carece de estudos empíricos que analisem o fenômeno das redes de stakeholders e da sua contribuição para o avanço da teoria. Assim, este trabalho tem como objetivo investigar a evolução da abordagem de redes de stakeholders nos últimos 20 anos e fornecer um panorama da sua evolução até os dias atuais. Este trabalho fundamenta-se em dois escopos de pesquisa: Teorias de Redes - sociedade em redes e redes interoganizacionais e a Teoria de Stakeholders, integradas na composição da proposta de Rowley (1997) -; Teoria de Redes de Stakeholders. Valendo-se da análise sociométrica e da revisão sistemática de 228 artigos coletados no Web of Science entre 1997 e 2017, foi possível analisar a evolução desta abordagem. Inferimos, por esta reflexão, que o interesse das pesquisas recentes deslocou-se das relações com os Stakeholders centradas na organização para as relações em rede descentralizadas e com diversos atores. Além disso, há uma tendência de estudos das redes formadas por grupos de stakeholders e estudos das identidades sociais dos indivíduos membros desses grupos. A contribuição deste estudo consiste em fornecer um panorama da Teoria de Redes de stakeholders, analisando as redes de referências, as contribuições teóricas e empíricas, as tendências de pesquisa, além de sugerir tópicos de pesquisa para trabalhos futuros. Palavras-chave: Múltiplos stakeholders. Redes interorganizacionais. Teoria dos stakeholders. Influência das partes interessadas. Análise sociométrica.

\section{Teoría de redes de influencia de stakeholders: un enfoque revisado}

\section{Resumen}

Las interacciones entre múltiples stakeholders han ganado importancia en las últimas décadas, dada la velocidad con la que se difunde la información y se establecen conexiones entre individuos y grupos. Sin embargo, todavía hay una brecha en la investigación, que es la falta de consolidación de estudios empíricos que analicen el fenómeno de las redes de stakeholders y su contribución al avance de la teoría. Por lo tanto, este trabajo tiene como objetivo investigar la evolución del enfoque de redes de stakeholders en los últimos 20 años, es decir, revisar la teoría de Rowley (1997) y presentar un panorama de su evolución hasta el presente. Este ensayo se basa en dos ámbitos de investigación: Teorías de redes -sociedad en redes y redes interorganizacionales y Teoría de Stakeholders (partes interesadas), integradas en la composición de la propuesta de Rowley (1997)- y, Teoría de redes de las influencias de stakeholders. A partir de un análisis sociométrico y una revisión sistemática de 228 artículos recopilados en Web of Science entre 1997 y 2017, fue posible analizar la evolución de este enfoque. Sobre la base de esta reflexión, es posible inferir que las investigaciones recientes cambian el enfoque de las relaciones con las partes interesadas, centradas en la organización, a las de una red descentralizada y con varios actores. Además, hay una tendencia de estudios de redes formadas por grupos de partes interesadas y las identidades sociales de los miembros individuales de estos grupos. La contribución de este estudio consiste en presentar un panorama de la teoría de redes de stakeholders analizando las redes de referencia, las contribuciones teóricas y empíricas, las tendencias de investigación, además de sugerir temas de investigación para trabajos futuros.

Palabras clave: Múltiples stakeholders. Redes interorganizacionales. Teoría de los stakeholders. Influencia de las partes interesadas. Análisis sociométrico. 


\section{INTRODUCTION}

Researchers and professionals from the area of strategy recognize that cooperation is fundamental for organizational success. Organizations can be considered as a system of cooperation and of coordinated efforts geared toward their end activities (BARNARD, 1938). Since the end of the 1930s, cooperation processes have been studied, especially in regard to the intra and interorganizational field (GIBBS and SINGER, 1993), networks (POWELL, 1990), and organizational alliances (CONTRACTOR and LORANGE, 1988).

In stakeholder theory, most of the research on cooperation has been focused on what is known as the field of interorganizational collaboration (GRAY and WOOD, 1991; HUXHAM and VANGEN, 1996; ROBERTS and BRADLEY, 1991). That is, the stakeholders relationship has been examined at the dyadic level, excluding the multiple and complex company structures. The relational results, emerging from the direct and indirect ties between the firm and its stakeholders, are only observed under the oneway relationship structure between the company and each one of its stakeholders (HEUGENS, VAN DEN BOSCH and VAN RIEL, 2002; ROWLEY, 1997).

Relational results are important for analyzing the behavior of companies and their stakeholders, since companies do not respond to each interested party individually, but instead in accordance with the multiple influences of an entire set of stakeholders (NEVILLE and MENGUC, 2006). This phenomenon characterizes so-called stakeholder networks, and analyzing it can reveal how relational results are obtained through the interactions between organizations and their multiple interested parties.

Therefore, stakeholder networks are relevant as a field of studies, considering that the traditional view of the company's relationship with its stakeholders is insufficient to explain the complexity of these relationships. Stakeholders relate with each other based on shared interests, they have collective capacities to influence the company's strategy (FROOMAN, 2010; SCHNEIDER and SACHS, 2017), they assume multiple roles with relation to an organization, and they are interlinked in a value creation system (HARRISON, FREEMAN and ABREU, 2015).

The leading theoretical approach in this field of studies is that of Rowley (1997), who proposes the Network Theory of Stakeholders. Through social network analysis, Rowley (1997) evaluates how the relationship occurs between multiple stakeholders, going beyond the dyadic relationships between them and a central organization. Even though it has theoretical and practical importance for studying the relationships between multiple stakeholders, the theoretical approach proposed has not shown relative evolution and application over recent years (ROWLEY, 2017).

Considering the current dynamics of the spread of information and of the establishment of connections between individuals and groups, the importance of the interactions between stakeholders has also grown in the last decades. However, there is still a lack of empirical studies that analyze the phenomenon of stakeholder networks and contribute to advancing the theory. Correspondingly, there is also the need to update and reinvigorate the theoretical premises that the research in the field is based on.

Therefore, this paper aims to investigate the evolution of the stakeholder networks approach, via a sociometric analysis and a systematic review of the publications on the theme in the last 20 years, since its conception in 1997. We elaborate an overview of the theoretical approach of social and stakeholder networks that presents: reference networks, theoretical and empirical contributions, and the trend in recent studies. Thus, this study contributes to the current debate on the topic, as well as helping in future research.

\section{THEORETICAL BACKGROUND}

The concept of networks originates from studies in sociology and in anthropology (JACK, 2010). The approach behind the concept, which is quite extensive, is associated with cross-cutting themes according to the different fields of the specialized literature, and generates different conceptions, such as that of social networks, that of organizational networks, and even that of stakeholder networks (PROVAN, FISH and SYDOW, 2007), the particular focus in this paper. 


\section{The social networks approach}

A network, according to Scott and Davis (2007), consists of "nodes" and "ties," or the relationships between the nodes. For the authors, the "nodes" are represented in a network by its actors, such as people, groups of individuals, organizations, or entities. Just as society is composed of a large network of interconnections (CASTELLS, MAJER and GERHARDT, 2002), in the context of organizations, the relationship dynamic also occurs in the form of interorganizational networks.

Advances in the methodology have enabled the networks metaphor to become a formal analysis method, in which new constructs and measures have been introduced, more rigorous systems have been established to test the theories, and new ways of thinking about organizations, their structures, and their relationships have been elaborated.

One of the premises of social network theory, according to Scott and Davis (2007), relates to the fact that a network is a system of relationships between parties, where the parties are generally referred to as "nodes", and the relationships or connections between those "nodes" are the "ties." From this perspective, the premise is that the ties influence the behavior of the actors in the network more than the specific attributes of the nodes themselves. Moreover, the behavior of a node is influenced not only by the ties with which it is directly involved, but also by the pattern of ties in the network.

Considering the dynamics of social networks, Granovetter (1985) defends his "embeddedness" proposal, in which the compression on the behaviors and the institutions to be analyzed should be weighted by the continuous social relationships in which they are immersed. Therefore, interpreting them as independent elements represents a serious misunderstanding, according to the author.

Thus, the organizational studies in recent years have also come to address the relationships between individuals, taking into account the modes of social relationships, whether from a broader or an individual perspective (GRANOVETTER, 2017).

In this aspect, it is important to highlight that, with the advent of technology, social networks have reconfigured. The structure on which the network society is based (CASTELLS, 1999) has potentially be expanded with advances in communication and information technologies, enabling new perspectives on the phenomenon, for example configuring networks as sociotechnical networks.

These "new arrangements" are described as networks in which technology provides the supporting structure for the social relationships that are established or will be established (LATOUR, 1994). Sociotechnical networks are like a new, more agile, and complex channel, which, considering their peculiarities, configure fertile ground for enabling the production and circulation of knowledge, and the emergence of new social forms (CALLON, 2004).

\section{The organizational networks approach}

As the economic environment has become global, technologically connected, and substantially more competitive, new organizational configurations have emerged, and networks have assumed growing strategic importance (GULATI, NOHRIA and ZAHEER, 2000). The evolution and continuous growth of these arrangements have given rise to a large research field, focused on analyzing the relationships within and among organizations (AHUJA, SODA and ZAHEER, 2012), which is clearly a hot topic in the literature (BERGENHOLTZ and WALDSTR $\varnothing \mathrm{M}, 2011$ ).

In the general context, organizational networks refer to the interactions between a set of organizations that transcend their organizational boundaries. In this sense, Gulati, Nohria and Zaheer (2000) argue that networks encompass a set of horizontal and vertical relationships of a company with other organizations, whether suppliers, customers, competitors, or other entities, and are composed of long-lasting interorganizational ties, with a strategic meaning for the companies.

Studies on the theme of organizational networks have increased in various areas of knowledge, such as sociology, economics, and business management (PROVAN, FISH and SYDOW, 2007). Organizational networks promote the sharing of knowledge, competences, and information, which are essential resources for competitiveness and for innovation (BALESTRIN and VERSCHOORE, 2016). Thus, by working in a network, organizations can achieve performance levels that they would find hard to achieve alone (ZACCARELLI, TELLES, SIQUEIRA et al., 2008).

With the phenomenon of globalization, new organizational structures have been formed and the form of organization in networks has gained even more importance. Acting as organizational intermediaries, the purpose of networks is to form environments so that certain organizations are able to outperform the strategic complexity of others (CASAROTTO FILHO and PIRES, 1998). 
Despite the various typologies of organizational networks, one common denominator among all is that they are constituted through complex and dynamic relational processes, ruled by strategic factors of competition and of cooperation, which characterize relational interdependence between the organizations (ROTH, WEGNER, ANTUNES JÚNIOR et al., 2012). Some networks can be decentralized, or not have a well-defined organizational structure, and others can be rigidly organized with high levels of centralization and control. But, in both scenarios, these arrangements are related to flexibility of the organizational form, with a view to achieving the objectives, without the need for standardization among the groups and the organizations belonging to the network (CASTELLS, 1999).

Thus, it can be affirmed that organizations are involved in organizational networks, with different degrees of centralization and formality, and that the organizational form based on relationships in a network enables a better orientation and development of corporate strategies (POWELL, 1990).

It is worth mentioning that the complexity of the organizational environment might make the dyadic approach to studying the relationships between actors in a network obsolete (YANG and BENTLEY, 2017). From the stakeholder perspective, the dyadic approach may not accompany the dynamic relationships that constitute society (CASTELLS, 2007). Thus, to understand the influence of stakeholders, one should incorporate the multiple relationships and more precisely describe the structures needed to promote stakeholder management (YANG and BENTLEY, 2017).

\section{The stakeholder networks approach}

Both in the classic theory on stakeholders, and in the current management models, strategic management is always presented from the perspective of a focal organization as the center of a network of stakeholders (ROWLEY, 1997). However, as companies compete in complex and interconnected markets with the same stakeholders, a bigger network with various focal points can be built (ROLOFF, 2008).

This approach has originated due to the interaction not only between the different stakeholders and a focal company. That is, besides the company's relationship with the stakeholders (FREEMAN and EVAN, 1990), there is also the relationship between the stakeholders, which leads companies to not respond individually to each one of them, but instead to the influence of the whole set of these relationships (ROWLEY, 1997).

Following the same line of reasoning as Rowley, Yang and Bentley (2017) affirm that corporations are not always the nexus of interactions, and instead, the internal and external social networks between stakeholders can affect the behaviors of organizations. In this sense, in his initial paper, Rowley $(1997$, p. 892) already argued that "[...] the focal organization is more than simply the central point of its own stakeholders: it is also a stakeholder of many other focal points in its relevant social system."

The importance of the social analysis of stakeholder network integration comes in response to a limitation of stakeholder theory, which concentrates more on the relationships between the central organization and its stakeholders, and less on the relationship between the stakeholders themselves and on the degree of mutual influence on each other's decisions, which may consequently influence the organization's results. For that reason, Rowley (1997) argues that, in many cases, the main influencers are not always directly linked to an organization, and that some stakeholders may be linked to the organization via other parties, such as via a bridge or interconnection.

Faced with this panorama, various researchers recognize the importance of an in-depth analysis of the relationships between stakeholders (ROWLEY and MOLDOVEANU, 2003; ROLOFF, 2008; GARRIGA, 2009; ZENG, CHEN, DONG et al., 2015; CABRAL, FERNANDES and RIBEIRO, 2016; ZEDAN and MILLER, 2017; YANG and BENTLEY, 2017). They suggest social network analysis to evaluate how the structure of the stakeholder network and the position of each stakeholder within that structure can influence the organization.

According to Rowley (1997), the link between those involved is evident, since the behavior of an organization and the resistance to the demands of its stakeholders are influenced by the density of the network of its stakeholders and by its location within that network. This is partly due (i) to the greater ease and intensity of information exchange the denser the network becomes, and also (ii) to the spread of common norms, behaviors, and expectations throughout the entire network, which makes it hard for organizations to isolate groups, retain information, or formulate strategies and alliances with conflicting objectives to others. 
According to Miles (2017), by exploring how structural factors restrict and shape the behavior of the actors in a particular stakeholder network, Rowley (1997) juxtaposed the concepts of centrality and density of networks. For the author, the existence of dense ties within and among the actors in a network of organizations facilitates the transfer of knowledge, behaviors, and expectations in the network. High density levels, considered as interconnectivity between the stakeholders in a network, are associated with high levels of coalitions and, therefore, a high level of power of those actors. Thus, the decision-making and management for the whole network are surrounded by more risks and derived from collective actions, and no longer from a centralizing decision-maker.

Revisiting the theory itself, Rowley (2017) affirms that the integration of social network analysis with the research on stakeholders remains limited up to now.

\section{METHODOLOGICAL PROCEDURES}

This paper investigates the evolution of the stakeholder networks approach, by carrying out a sociometric analysis and a systematic review of the publications on the topic in the last 20 years. The temporal cut-off was defined considering as an initial milestone of this approach the publication of the article by Timothy J. Rowley, in the Academy of Management Review, entitled "Moving beyond dyadic ties: A network theory of stakeholder influences," in 1997. The temporal cut-off covers a period of 20 years, from the publication of the aforementioned article up to 2017, when the author published a rereading of his theory entitled "The power of and in stakeholder networks."

Figure 1 shows the methodological procedures for the data collection, carried out by mapping the international literature in the Web of Science (ISI) database, filtering by journals belonging to the Business \& Management category. This database was chosen as it is "[...] one of the most comprehensive databases of pair-reviewed journals in the social sciences" (CROSSAN and APAYDIN, 2010, p. 1157), and it contains only well-recognized content that is considered relevant by peers (SCARINGELLA and RADZIWON, 2017).

Figure 1

Matrix of the stages and methodological procedures

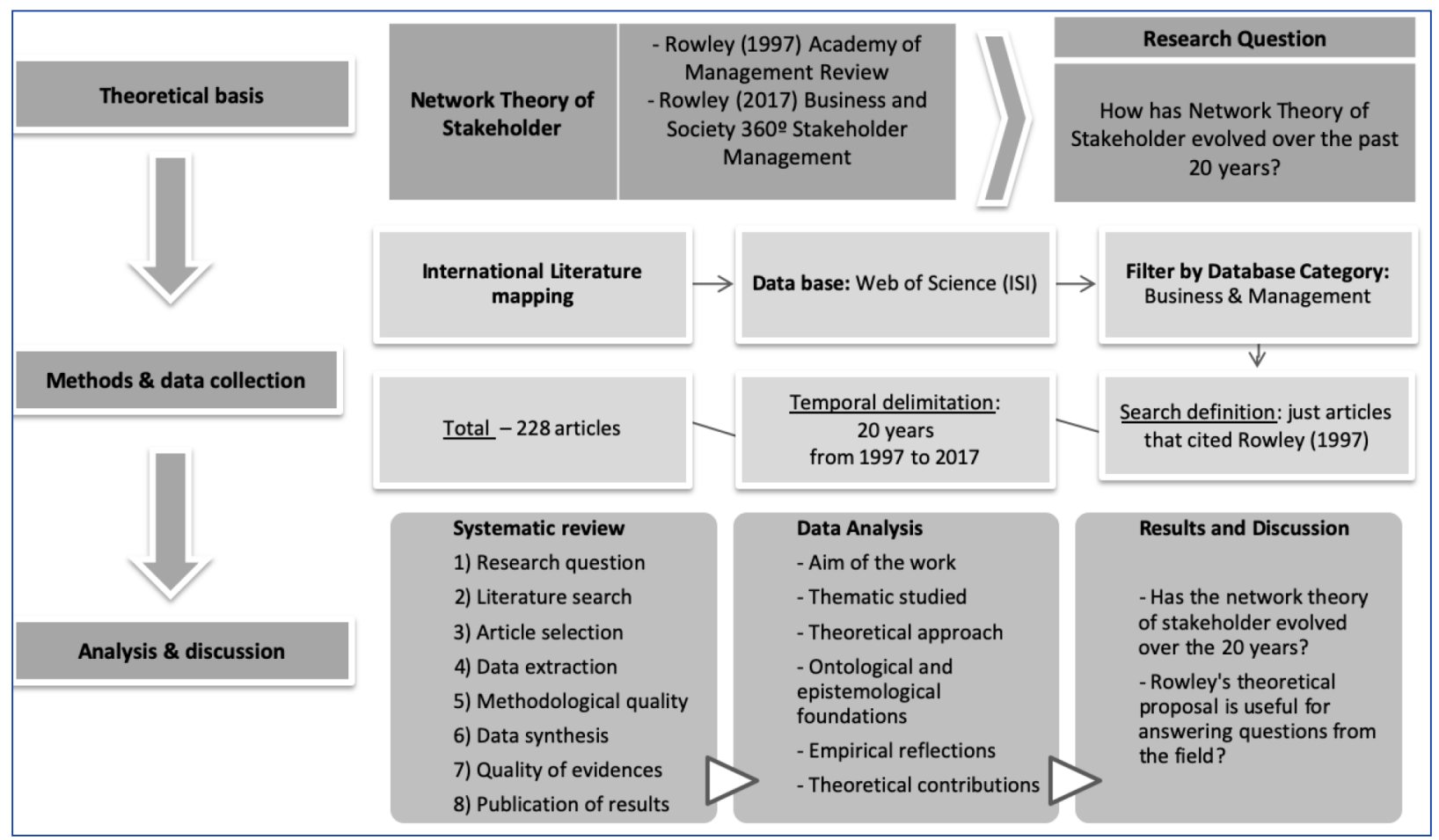

Source: Elaborated by the authors. 
All the articles were identified in the aforementioned database that cite the article "Moving beyond dyadic ties: A network theory of stakeholder influences", by Rowley (1997), resulting in a total of 228 papers. It should be noted that the citation itself may represent agreement, disagreement, and/or additions made to the initial work. Therefore, they represent the interest of the review, carried out in this study, in mapping the evolution of Rowley's theory.

\section{Sociometric analysis of the data}

Initially, the data were subjected to sociometric analysis with a view to classifying the articles in a structural and organized way, and finding patterns and links between them. Then, the most cited articles or those with the greatest adherence to the focus of the study were analyzed, defined as the social networks analysis for the stakeholders approach.

Sociometric analysis enables relational networks to be detected, converting qualitative into quantitative information, and allowing the data to be tabulated and transformed into graphics that enable the individual situation of each element in the group to be visualized (RIBEIRO, ANTONIALLI and ZAMBALDE, 2015).

Sociometry also confirms the existence of characteristic patterns of the organization of groups, their expressions, and own configurations (VAN ECK and WALTMAN, 2014). The results of the analyses can be examined at three levels: at the individual level; at the level of the interpersonal relationships; and at the level of the structures of the groups. In this research, sociometric analysis is employed with the aim of analyzing the map of co-citations of all the authors resulting from the data collection, and also to analyze the evolution of the bibliographic production concerning the theme studied, analyzing the most cited papers and the most used keywords. The software used for the sociometric data analysis was VOSviewer ${ }^{\circledR}$ version 1.6.6.

\section{SYSTEMATIC REVIEW OF THE LITERATURE}

The systematic review of the literature was based on pre-determined criteria and consistent scientific evidence, with the aim of supporting the choice of studies and/or analytical and methodological possibilities for the development of the research question raised (SAUR-AMARAL, 2010). According to Hackett and Dilts (2004), the systematic review method is a rigorous methodology proposed to: identify the studies on a topic in question, applying explicit and systematized search methods; evaluate the quality and validity of those studies, as well as their applicability. That is, it concerns an investigation based on a specific question, in which the aim is to identify, analyze, and synthesize important evidence available in the field. The stages of the systematic review were undertaken in this study as described in Figure 1.

With relation to the presentation of the results of the data analyzed, the article is structured as follows: 1) description and sociometric analysis of the data, with a presentation of the co-citation analysis, including a co-citation cluster network, bibliographic coupling cluster network, and illustration of the mapping of the theoretical clusters found; 2) empirical applications of the Network Theory of Stakeholders, with an analysis of the empirical studies that use Rowley's model to develop the research, including the main results and assumptions of each study; 3 ) theoretical evolution of the stakeholder networks approach, addressing the papers that have cited, discussed, and complemented Rowley's model; 4) synthesis of the evolution of the stakeholder networks approach; 5) discussion of trends and research agenda proposal.

\section{RESULTS AND ANALYSIS OF THE DATA}

Using the data collection procedures, 228 articles were obtained that cite the Network Theory of Stakeholders in the period from 1997 to 2017. Of the total articles found, 64 were classified as empirical articles, corresponding to $28 \%$ of the sample, which reveals the emphasis of this field of studies on the theoretical development of the networks and stakeholders approach. 


\section{Description and sociometric analysis of the data}

The sociometric analysis was undertaken of all 228 articles from the database used for the collection. Using sociometry, it was identified who the most jointly cited authors were in the articles (co-citation), which helps in the analysis of a large number of publications due to the theoretical perspectives adopted. Figure 2 presents the first result of the sociometric analysis, the co-citation cluster network.

As observed in Figure 2, the sample is segmented into three clusters, obtained with the help of the VOSviewer software. In the first cluster (in red), the authors Rowley, Gulati, and Powell stand out, among others. In the second cluster (in green), the authors Freeman, Donaldson, and Phillips stand out. In the third cluster (in blue), Porter, Wood and Waddock stand out, among others. These authors are the most cited in the co-citation networks, and may have more than one paper published on the theme.

Figure 2

\section{Co-citation cluster network}

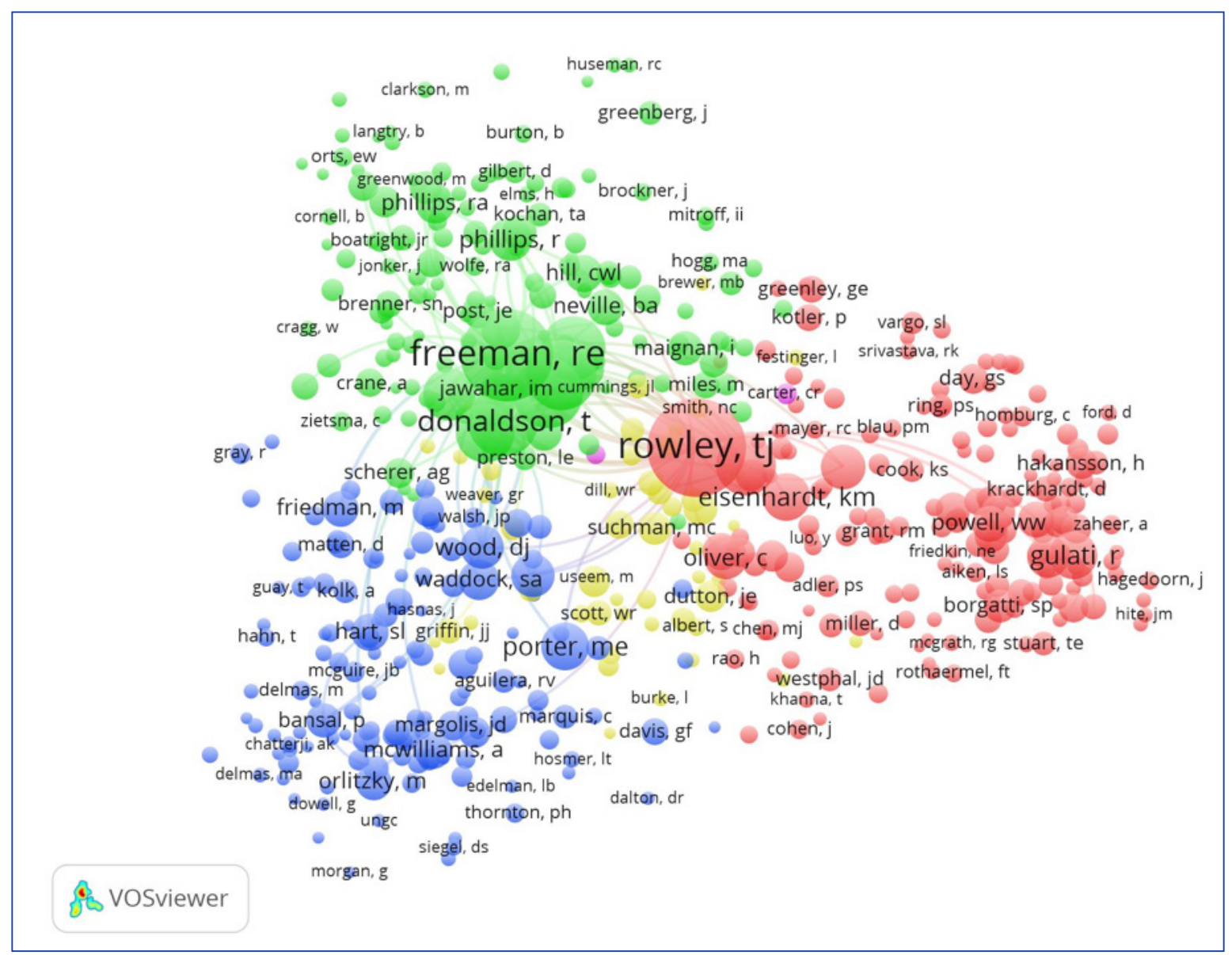

Source: Elaborated by the authors.

In addition to the analysis and identification of the citation patterns of the articles analyzed, the bibliographic coupling cluster network was elaborated, which aims to group the references based on the paper cited. Figure 3 presents the result of the bibliographic coupling cluster network.

The bibliographic coupling presented in Figure 3 reinforces the grouping of the sample into three clusters. Most of the citations are concentrated in the first two clusters. In the first cluster (in red), the most cited article is that of Rowley (1997); in the second cluster (in green), the most cited paper is that of Freeman (1984); in the third cluster, there is a more homogenous distribution of the citations, featuring the papers by Barney (1991), Agle, Mitchell and Sonnenfeld (1999), and Berman, Wicks, Kotha et al. (1999), among others. 
Figure 3

\section{Bibliographic coupling cluster network}

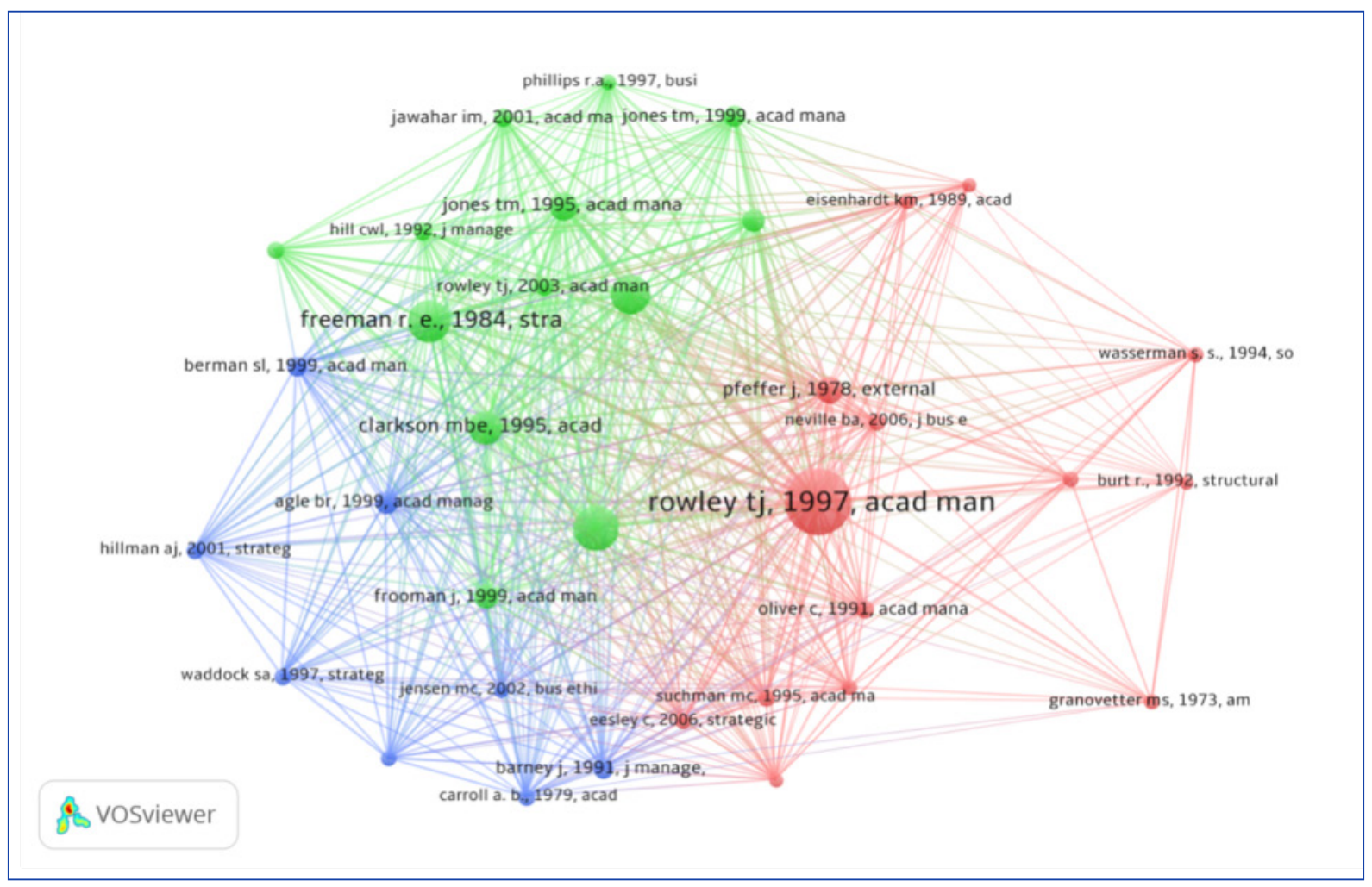

Source: Elaborated by the authors.

The in-depth analysis of the co-citations obtained via sociometry identified three clusters, named as follows: Cluster 1 - Social Network Theory; Cluster 2 - Stakeholder Theory; and Cluster 3 - Organizational Theory. Figure 4 presents the main citations in each cluster, considering both the analysis of the authors and the analysis of the papers.

Figure 4

\section{Categorization of the mapping of the theoretical clusters}

\begin{tabular}{|c|c|c|}
\hline $\begin{array}{c}\text { Cluster 1: Social Network } \\
\text { Theory }\end{array}$ & Cluster 2: Stakeholder Theory & $\begin{array}{c}\text { Cluster 3: Organizational } \\
\text { Theory }\end{array}$ \\
\hline $\begin{array}{l}\text { - Granovetter (1985) } \\
\text { - Pfeffer and Salancik (1978) } \\
\text { - Pfeffer and Salancik (1978) } \\
\text { - Powell (1990) } \\
\text { - Burt (1997) } \\
\text { - Rowley (1997) }\end{array}$ & $\begin{array}{l}\text { - Freeman (1984) } \\
\text {-Donaldson and Preston } \\
\text { (1995) } \\
\text { - Clarkson (1995) } \\
\text { - Jones and Wicks (1999) } \\
\text { - Phillips (2003) } \\
\text { - Rowley and Moldoveanu } \\
\text { (2003) }\end{array}$ & $\begin{array}{l}\text {-Porter (1980) } \\
\text { - Barney (1991) } \\
\text { - Carroll (1979) } \\
\text {-Waddock and Graves (1997) } \\
\text { - Jensen (2002) }\end{array}$ \\
\hline
\end{tabular}

Source: Elaborated by the authors. 
Cluster 1, called Social Network Theory, features a concentration of the fundamental publications in network theory. This cluster has social and organizational networks as its main theme of study, also seeking to understand the influence of stakeholders on organizations. Cluster 2, called Stakeholder Theory, groups studies whose framework is supported by stakeholder theory. The articles in this cluster focus their contribution on the stakeholder approach and on the different ways stakeholders influence organizations. Cluster 3, called Organizational Theory, aims to contribute to understanding the competitive advantages of organizations, and is also based on studies that investigate social performance for stakeholders.

Finally, with the sociometric analysis of the clusters of studies, it was also possible to visualize the main keywords cited in each cluster, as described in Figure 4. The keyword analysis reinforces the characteristics of the clusters of studies. In the first cluster, there is an emphasis on the studies about stakeholder networks, with keywords such as effect, impact, importance, and centrality being recurrent. In the second cluster, the keywords refer to stakeholder theory, relationship with stakeholders, interests, legitimacy, and other terms linked to the evolution of the studies of stakeholder theory. In the third group, there is an emphasis on conceptual and methodological aspects, with terms such as methodological design, concepts, practical implications, and society. A last cluster was also formed with the terms performance and resources, among others. Therefore, the studies that compose the sample contribute both to the literature on networks of organizations and to the stakeholders and corporate strategy literature.

Figure 5

\section{Keywords cluster}

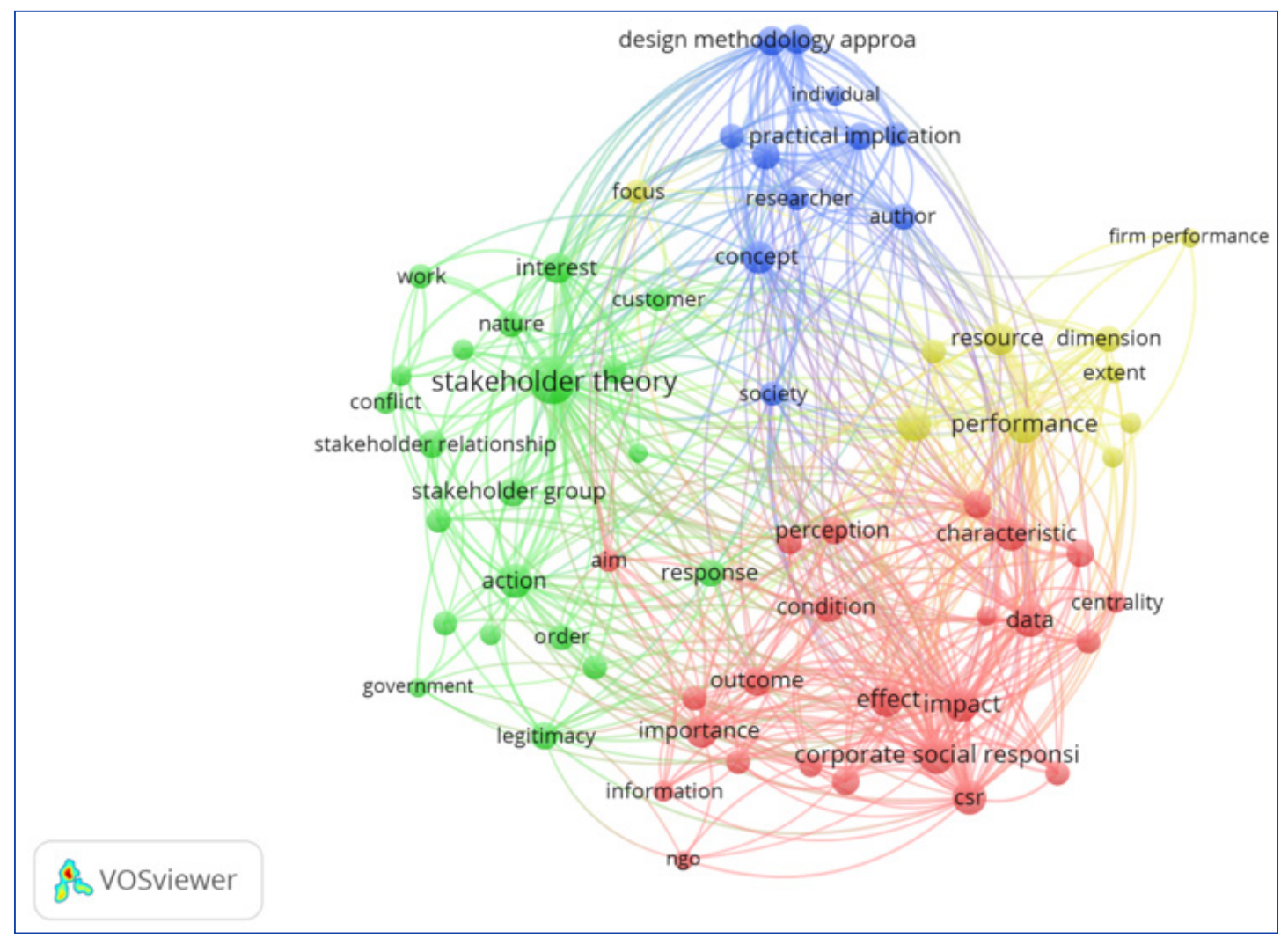

Source: Elaborated by the authors.

After the sociometric analysis of the data, the systematic review was carried out of the set of publications, observing: objectives of the papers, theme studied, theoretical approach used, empirical reflections, and resulting contributions. Of the 228 articles analyzed, 64 are theoretical-empirical (28\%), and, of these, 39 are case studies (17\%). The contributions of the empirical articles were analyzed and it was observed that three of these studies seek to apply and expand the model from Rowley (1997). The empirical studies are those of Garriga (2009), Fassin, Colle and Freeman (2017), and Zedan and Miller (2017). 
The choice of empirical articles is warranted here due to the objective of this study being to reveal the stakeholder networks approach as practice, aiming to understand how it has developed empirically in the last 20 years, that is, since it was proposed.

\section{Empirical Applications of the Network Theory of Stakeholders}

Fassin, Collee and Freeman (2017) analyze different decisions to close industrial plants in multinational companies, applying the stakeholder theory approach. The main argument of the article is based on the emergence of alliances between stakeholders interested in a specific organization. The research by Fassin, Collee and Freeman (2017) was carried out in an environment of strategic decisions in the multinational breweries sector, located in small cities in Italy and in Belgium, in which there was interest, on the part of the company, in closing down corporate activities. In both cases, the initial decision to close down the activities was reversed, thanks to the actions and demands of the stakeholder alliances. At the end, among other propositions, the authors argue that intra-stakeholder alliances can have an overwhelming influence on corporate strategy, a relationship hypothesized by Stocker and Mascena (2019).

Based on the gap in empirical research that explains the cooperation process using the stakeholder theory approach, Garriga (2009) carried out an in-depth, inductive case study, combining quantitative sociometric data and qualitative theorybased and ethnographic observation data. For the inductive case study, the researcher adopted the Natural Gas Pipeline Program developed in Buenos Aires, Argentina. Analyzing the various interactions between the multiple stakeholders and a particular focal organization, Garriga (2009) concludes that there is an overlap of the interests of the stakeholders, formed of pluralities of individuals that occupy different social roles and belong to different groups of stakeholders. Only using the social networks approach would it be possible to make these interlocutions and understand the influence of these multiple actors on the decisions and strategies of companies, which aligns with the arguments of Rowley (1997) and Rowley and Moldoveanu (2003).

Another study based on the concepts and on the approach of the Network Theory of Stakeholders is that of Zedan and Miller (2017), which seeks to explore the impact of the influence of stakeholders on strategic decisions in the engineering and energy efficiency sector. The article concluded that the stakeholders network has more connectivity with the strategic decisions than expected by the focal organizations, and that the transparency and sharing of information with the stakeholders regarding the companies' decisions have a positive impact on the response that the stakeholders group gives to the companies.

The authors present the mapping of the social relationships between the different stakeholders, and the more the density and centrality metrics are applied, the more interconnected the relationships appear, and the more influences are revealed between the focal organizations and their various stakeholders. Social network analysis is a strategy for investigating the degree of influence of each actor, since, using the centrality metrics, it is observed how they can impact on each other, as well as the level of connection and cohesion within the network. Thus, from using the social networks methodology for stakeholders analysis, it can be said that those stakeholders with high centrality are more likely to influence others and have greater power within the network (ZEDAN and MILLER, 2017).

\section{Theoretical evolution of the stakeholder networks approach}

The approach based on stakeholder networks, also defined as a set of interdependent actors affected by an organization (SCHNEIDER and SACHS, 2017), is a relevant source of resources for the creation of organizational value (RÜHLI, SACHS, SCHMITT et al., 2017; BRIDOUX and STOELHORST, 2016; SCHNEIDER and SACHS, 2017).

Unlike other strategic management theories, the researchers consider that stakeholder theory incorporates value creation as one of the relational contributions between an organization and its stakeholders (FREEMAN, 1984; DONALDSON and PRESTON, 1995; HARRISON and WICKS, 2013; TANTALO and PRIEM, 2016; BRANDÃO, DIÓGENES and ABREU, 2017). In relation to the question of value creation, Rowley (1997) considers that the organization, as a focal actor in a network of relationships with multiple stakeholders, is able to access the resources and capacities of each stakeholder, and to become involved in a value creation process (SCIARELLI and TANI, 2013). 
In this set of studies there are few analyses of the underlying processes of value creation in the stakeholder networks approach (SCHNEIDER and SACHS, 2017). Specifically, there is a need to investigate the prior conditions that lead to cooperation and fair behavior of individuals in multiple stakeholder environments (HARRISON and WICKS, 2013).

The recent study presented by Ali (2007) is also based on the stakeholder network approach. The author argues that the role of the managers in a network is a little diluted, and recognizes the agency of the stakeholders. In this vision, companies are seen as part of a network whose density and centrality decide how much they can be influenced by certain stakeholders, thus supporting the affirmations of Rowley (1997). It also has to be considered that organizational survival and prosperity depend on the expectations of the various stakeholder groups, and not only on the interests of the organization itself and of the managers that form part of it (GRIFFIN, 2017).

\section{Synthesis of the evolution of the stakeholder networks approach}

To synthesize the evolution of the stakeholder networks approach, Table 1 presents: a) the main proposal of Rowley's model; b) the original propositions presented in the seminal article by the author; c) the empirical reflections of the studies developed using the model; d) the theoretical reflections on the model and possible additions to the theory; and, finally, e) the highlights of the network theory of stakeholders.

\section{Table 1}

\section{Synthetic framework of the network theory of stakeholders}

\begin{tabular}{|c|c|c|c|}
\hline $\begin{array}{l}\text { Main Assumption of } \\
\text { the Network Theory } \\
\text { of Stakeholders }\end{array}$ & \multicolumn{3}{|c|}{$\begin{array}{l}\text { The social networks construction model (density and centrality) proposes to go beyond the traditional analysis of dyadic } \\
\text { ties and considers the influences and impact of the different stakeholders that do not have direct relationships with } \\
\text { the focal company, but that affect the behavior of the company and of the entire network (ROWLEY, 1997, p. 907) }\end{array}$} \\
\hline $\begin{array}{l}\text { Propositions of } \\
\text { Rowley (1997) }\end{array}$ & $\begin{array}{l}\text { Proposition 1: The more the density } \\
\text { of the network increases, the more } \\
\text { the capacity of the stakeholders of } \\
\text { a focal organization to restrict the } \\
\text { organization's actions increases. }\end{array}$ & $\begin{array}{l}\text { Proposition 2: The more the centrality } \\
\text { of the focal organization increases, the } \\
\text { more its capacity to resist pressures } \\
\text { from the stakeholders increases. }\end{array}$ & $\begin{array}{l}\text { Proposition 3: In different density } \\
\text { and centrality conditions, the focal } \\
\text { organization will adopt a more active } \\
\text { or subordinate role regarding the } \\
\text { interests and expectations of the } \\
\text { whole stakeholders network. }\end{array}$ \\
\hline $\begin{array}{l}\text { Empirical reflections } \\
\text { on Rowley's theory }\end{array}$ & $\begin{array}{l}\text { Only by using the social networks } \\
\text { approach is it possible to make the } \\
\text { interlocutions of the social roles to } \\
\text { understand the influence of the mul- } \\
\text { tiple actors on the decisions and stra- } \\
\text { tegies of companies (GARRIGA, 2009). }\end{array}$ & $\begin{array}{l}\text { The stakeholders network has more } \\
\text { connectivity with strategic decisions } \\
\text { than expected by the focal organiza- } \\
\text { tions (ZEDAN and MILLER, 2017). }\end{array}$ & $\begin{array}{l}\text { Intra-stakeholder alliances can have } \\
\text { an overwhelming influence on cor- } \\
\text { porate strategy (FASSIN, COLLE and } \\
\text { FREEMAN, 2017). }\end{array}$ \\
\hline $\begin{array}{l}\text { Theoretical } \\
\text { reflections on } \\
\text { Rowley's theory }\end{array}$ & $\begin{array}{l}\text { The social analysis of stakeholder net- } \\
\text { works is a relevant source of resour- } \\
\text { ces for organizational value creation } \\
\text { (SCHNEIDER and SACHS, 2017). }\end{array}$ & $\begin{array}{l}\text { From using the model, it is possible to } \\
\text { identify the resources and capacities of } \\
\text { each stakeholder, to then get involved } \\
\text { in a value creation process (SCIARELLI } \\
\text { and TANI, 2013). }\end{array}$ & $\begin{array}{l}\text { Companies are seen as part of a net- } \\
\text { work whose densities and centrality } \\
\text { determine how much they can be } \\
\text { influenced by their stakeholders } \\
\text { (ALI, 2017). }\end{array}$ \\
\hline $\begin{array}{l}\text { Highlights of the } \\
\text { theory }\end{array}$ & $\begin{array}{l}\text { The proposed model helps in defining } \\
\text { the boundaries of the network to be } \\
\text { studied. }\end{array}$ & $\begin{array}{l}\text { The relational ties between the actors } \\
\text { are channels for the transfer or "flow" } \\
\text { of resources and value creation. }\end{array}$ & $\begin{array}{l}\text { It principally considers how the pat- } \\
\text { tern of relationships between the } \\
\text { multiple actors as a whole affects } \\
\text { the members of the network. }\end{array}$ \\
\hline
\end{tabular}

Source: Elaborated by the authors.

In light of the arguments summarized in this framework, it is necessary to ponder that, in his seminal paper, Rowley (1997) only considered in his propositions the density and centrality variables as influential in the interaction between the organization and its stakeholders. However, given the advent of the internet and communication and information technologies in general, studying social evolutions has become unfeasible without considering the impact of these technological advances on the interactional dynamic of the individuals and groups that produce and use them. 
Although this aspect did not emerge in the studies reviewed, it is necessary to consider that characteristic elements of sociotechnical networks (LATOUR, 1994), given their capacity to modify relational channels, reconfiguring connections and flows of content, should be integrated into the analysis. In this aspect, there is a noted need to include elements such as the connectivity, reach, and engagement of the relational actors when analyzing the interaction between the organization and its stakeholders. Indeed, just like the formation of social and/or organizational networks, the formation of virtual communities (sociotechnical networks) is also based on interconnection and involves compatibility of interests and a wide process of exchange and cooperation.

\section{Research trends}

Based on the theoretical reflection on the stakeholder networks approach, it is possible to infer that the recent studies are shifting the focus from the relationships with stakeholders centered on the organization toward relationships of a decentralized network with various actors. Moreover, some researchers such as Schneider and Sachs (2017) and Bridoux and Stoelhorst (2014) are also exploring, as a unit of analysis for the studies, stakeholder networks and the social identities of the members of these groups, going beyond the traditional analysis with a focus on the company, to understand the behaviors, attitudes, and perceptions of the individuals affiliated with stakeholder networks.

This new research approach is also aligned with the recent studies from the strategy area (BRIDOUX and STOELHORST, 2014; SCHNEIDER and SACHS, 2017) that explore the microfoundations for the creation of organizational value, and how the cooperative behaviors among stakeholders influence the performance of organizations around them.

Thus, it is argued that conceptualizing stakeholders as social groups and studying their relationships via social networks is still a relevant field of studies, considering the same arguments presented by Rowley (1997) and Rowley and Moldoveanu (2003). The stakeholders network is also revealed to be an important additional unit of analysis, promoting the development and application of research instruments at various levels to investigate the development of capacities, resources, and knowledge, as well as value creation, based on the stakeholder networks perspective.

In light of the analyses and research trends presented, some topics are proposed below, for future studies of the stakeholder networks approach.

- Analyzing how stakeholder influence networks contribute to value creation through strategic synergy actions (TANTALO and PRIEM, 2016), that is, actions that benefit various stakeholders simultaneously.

- Evaluating how the influence of stakeholder networks, organized around a common interest (SCHNEIDER and SACHS, 2017), affect companies and their relationship with the multiple stakeholders.

- Empirically describing how the social identities of the individuals inserted in stakeholder networks model their affiliation and commitment with relation to a focal company.

- Analyzing the influence capacity of actors that assume different roles in relation to an organization (that is, the same individual assuming the role of shareholder and of consumer, or of shareholder and of employee simultaneously) from the social networks perspective.

- Developing or improving joint value creation or value co-creation models (BRIDOUX and STOELHORST, 2016) from the perspective of the cooperation in a network of multiple stakeholders.

- Evaluating the relational gains in the engagement of stakeholders, from the perspective that the individuals inserted in networks develop collective behaviors of social participation.

- Identifying negative impacts on the organizational reputation derived from the behavior of stakeholders in networks, such as boycotts and the disclosure of negative information.

- Identifying other approaches that benefit from the inter-relationship between stakeholder networks, from an interdisciplinary perspective. 


\section{CONCLUDING REMARKS AND IMPLICATIONS}

Analysis of the stakeholder networks approach is revealed to be promising for studies that seek to investigate the interconnections between multiple stakeholders and their influence on organizations. It was observed that this approach has a relationship with social network theory, with stakeholder theory, and with organizational theory, and for each theoretical line there are prominent authors who influence the publications.

The stakeholder networks approach presents advantages for the theoretical, empirical, and managerial field. It contributes to defining the boundaries of an organizational network, which may lead to more effective stakeholder management. It also stands out for the potential for value creation and resource exchange between actors, promoting cooperation and synergy. Finally, the approach plays an important role in the strategic process, given that the influence of the actors in a network has an impact on the adoption of strategies.

The considerations raised by this study were based on the theoretical and empirical works published on stakeholder networks in the last 20 years. The propositions of Rowley (1997) are rediscussed and, in a way, added to by researchers such as Roloff (2008), Zeng, Chen, Dong et al. (2015), and Yang and Bentley (2017), among others, who recognize the importance of an in-depth analysis of the relationships between stakeholders. As presented and discussed in the synthetic framework on the evolution of the theoretical approach of stakeholder theory, both the empirical articles analyzed, for example Garriga (2009) and Fassin, Cole and Freeman (2017), and also the theoretical articles that focus in more depth on the use of Rowley's model, such as Schneider and Sachs (2017), Sciareli and Tani (2013), and Ali (2017), recognize the importance of using social network analysis to examine how the structure of a stakeholders network and the position of each stakeholder within that structure can influence the organization.

Based on the theoretical reflection on the stakeholder networks approach, it is possible to infer that the recent studies are shifting the focus from the stakeholder relationships centered on the organization toward the relationships of a decentralized network with various actors. This question reflects the interconnection between the theoretical fields of organizational networks and the studies supported by the stakeholder theory approach, as observed in the studies by Provan, Fish and Sydow (2007) and Yang and Bentley (2017). It is revealed that there is a trend of studies on stakeholder networks that go beyond the traditional analysis with a focus on the company, and that seek to understand, through the social identities of the members affiliated with the network, their behaviors, attitudes, and perceptions. Moreover, as revealed in the research trends proposal, which was based on the studies of Schneider and Sachs (2017) and Bridoux and Stoelhorst (2014), other research possibilities emerge, primarily with the evolution of stakeholder theory itself, which has contributed to the high number of publications in recent years.

This study has its recognized limitations. First, as the objective was to present the evolution of the stakeholder networks approach based on the proposal from Rowley $(1997,2017)$, other studies that have been elaborated by combining social network theory and stakeholder theory, but independently from the publication by Rowley (1997), were not included in this review. Although the studies, in this area in particular, were outside the defined scope, it is recognized that they could be important for better understanding how these theories come together, are operationalized, and contribute to the organizational literature in general. Second, the exclusive criterion of selecting peer-reviewed articles from the ISI database, in the area of Business \& Management, may have omitted some relevant study. Consequently, additional studies are recommended to investigate other databases. Moreover, it is important to implement studies with other Boolean operators that contemplate terms related to social and stakeholder networks.

Despite these limitations, it is recognized that the contribution of this study lies in the elaboration of a theoretical overview of the social networks approach for stakeholders analysis, presenting reference networks, theoretical and empirical contributions, and the trend in recent studies, and thus helping future research on this theme. 


\section{REFERENCES}

AGLE, B. R.; MITCHELL, R. K.; SONNENFELD, J. A. Who matters to CEOs? An investigation of stakeholder attributes and salience, corporate performance, and CEO values. Academy of Management Journal, v. 42 , n. 5, p. 507-525, 1999.

AHUJA, G.; SODA, G.; ZAHEER, A. The genesis and dynamics of organizational networks. Organization Science, v. 23, n. 2, p. 434 448, 2012.

ALI, M. A. Stakeholder salience for stakeholder firms: An attempt to reframe an important heuristic device. Journal of Business Ethics, v. 144, n. 1, p. 153-168, 2017.

BALESTRIN, A.; VERSCHOORE, J. Redes de Cooperação Empresarial: Estratégias de Gestão na Nova Economia. Porto Alegre: Bookman Editora, 2016.

BARNARD, C. I. The Functions of the Executive. Cambridge Mass.: Harvard University Press, 1938.

BARNEY, J. Firm resources and sustained competitive advantage. Journal of Management, v. 17, n. 1, p. 99-120, 1991.

BERGENHOLTZ, C.; WALDSTR $\varnothing \mathrm{M}, \mathrm{C}$. Inter-organizational network studies - a literature review. Industry and Innovation, v. 18, n. 6 , p. $539-562,2011$.

BERMAN, S. L. et al. Does stakeholder orientation matter? The relationship between stakeholder management models and firm financial performance. Academy of Management Journal, v. 42, n. 5, p. 488-506, 1999.

BRANDÃO, I. F.; DIÓGENES, A. S. M.; ABREU, M. C. Value allocation to stakeholder employees and its effect on the competitiveness of the banking sector. Revista Brasileira de Gestão de Negócios, v. 19, n. 64 , p. 161-179. 2017.

BRIDOUX, F.; STOELHORST, J. W. Microfoundations for stakeholder theory: Managing stakeholders with heterogeneous motives. Strategic Management Journal, v. 35, n. 1, p. 107-125, 2014.

BRIDOUX, F.; STOELHORST, J. W. Stakeholder relationships and social welfare: A behavioral theory of contributions to joint value creation. Academy of Management Review, v. 41, n. 2, p. 229251, 2016.

BURT, R. S. A note on social capital and network content. Social networks, v. 19, n. 4, p. 355-373, 1997.

CABRAL, S.; FERNANDES, A. S. A.; RIBEIRO, D. B. C. Os papéis dos stakeholders na implementação das parcerias público-privadas no Estado da Bahia. Cadernos EBAPE.BR, Rio de Janeiro, v. 14, n. 2, p. 325-339, 2016.

CALLON, M. Por uma nova abordagem da ciência, da inovação e do mercado: o papel das redes sócio-técnicas. In: PARENTE, A. (Org.). Tramas da rede: novas dimensões filosóficas, estéticas e políticas de comunicação. Porto Alegre: Sulina, 2004. p. 64-79.

CARROLL, A.B. A three-dimensional conceptual model of corporate performance. Academy of management review, v. 4, n. 4, p. 497505, 1979.

CASSAROTO FILHO, N.; PIRES, L. H. Redes de pequenas e médias empresas e desenvolvimento local: estratégia para conquista da competitividade global com base na experiência italiana. São Paulo: Atlas, 1998.

CASTELLS, M. Para o Estado-rede: globalização econômica e instituições políticas na era da informação. In: BRESSER-PEREIRA, L. C.; SOLA, L.; WILHEIM, J. (Org.). Sociedade e Estado em transformação. São Paulo: Editora UNESP, 1999. p. 147-171.

CASTELLS, M. Communication, power and counter-power in the network society. International Journal of Communication, v. 1, p. 238-266, 2007.

CASTELLS, M.; MAJER, R. V.; GERHARDT, K. B. A sociedade em rede. Lisboa: Fundação Calouste Gulbenkian, 2002.

CLARKSON, M. E. A stakeholder framework for analyzing and evaluating corporate social performance. Academy of management review, v. 20, n. 1, p. 92-117, 1995.

CONTRACTOR, F. J.; LORANGE, P. Why should firms cooperate? The strategy and economics basis for cooperative ventures. In: CONTRACTOR, F.; LORANGE, P. (Eds.). Cooperative Strategies in International Business. Massachusets: Lexington Books, 1988. p. 3-30.

CROSSAN, M. M.; APAYDIN, M. A multi-dimensional framework of organizational innovation: A systematic review of the literature. Journal of Management Studies, v. 47, n. 6, p. 1154-1191, 2010.

DONALDSON, T.; PRESTON, L. E. The stakeholder theory of the corporation: Concepts, evidence, and implications. Academy of Management Review, v. 20, n. 1, p. 65-91, 1995.

FASSIN, Y.; COLLE, S.; FREEMAN, R. E. Intra-stakeholder alliances in plant-closing decisions: A stakeholder theory approach. Business Ethics: A European Review, v. 26, n. 2, p. 97-111, 2017.

FREEMAN, R. E. Strategic management: A stakeholder approach. Boston: Pitman, 1984.

FREEMAN, R. E.; EVAN, W. M. Corporate governance: A stakeholder interpretation. Journal of Behavioral Economics, v. 19, n. 4, p. 337359, 1990.

FROOMAN, J. The issue network: Reshaping the stakeholder model. Canadian Journal of Administrative Sciences, v. 27, n. 2, p. 161173, 2010.

GARRIGA, E. Cooperation in stakeholder networks: firms' 'Tertius lungens' role. Journal of Business Ethics, v. 90, n. 4, p. 623-637, 2009.

GIBBS, B. H.; SINGER, J. D. Empirical knowledge on world politics: A summary of quantitative research, 1970-1991. Westport: Greenwood Pub Group, 1993.

GRANOVETTER, M. Economic action and social structure: The problem of embeddedness. American Journal of Sociology, v. 91, n. 3, p. 481-510, 1985.

GRANOVETTER, M. Society and economy: Framework and principles. Cambridge: Harvard University Press, 2017.

GRAY, B.; WOOD, D. J. Collaborative alliances: Moving from practice to theory. The Journal of Applied Behavioral Science, v. 27, n. 1, p. 3-22, 1991. 
GRIFFIN, J. J. Tracing stakeholder terminology then and now: Convergence and new pathways. Business Ethics: A European Review, v. 26, n. 4, p. 326-346, 2017.

GULATI, R.; NOHRIA, N.; ZAHEER, A. Strategic networks. Strategic Management Journal, v. 21, n. 3, p. 203-215, 2000.

HACKETT, S. M.; DILTS, D. M. A systematic review of business incubation research. The Journal of Technology Transfer, v. 29, n. 1, p. 55-82, 2004.

HARRISON, J.; FREEMAN, E.; ABREU, M. C. S. Stakeholder Theory as an ethical approach to effective management: applying the theory to multiple contexts. Revista Brasileira de Gestão de Negócios, v. 17 , n. 55 , p. $858-869.2015$

HARRISON, J. S.; WICKS, A. C. Stakeholder theory, value, and firm performance. Business Ethics Quarterly, v. 23, n. 1, p. 97-124, 2013.

HEUGENS, P.; VAN DEN BOSCH, F. A. J.; VAN RIEL, C. Stakeholder integration: Building mutually enforcing relationships. Business \& Society, v. 41, n. 1, p. 36-60, 2002.

HUXHAM, C.; VANGEN, S. Working together: Key themes in the management of relationships between public and non-profit organizations. International Journal of Public Sector Management, v. 9, n. 7, p. 5-17, 1996.

JACK, S. L. Approaches to studying networks: Implications and outcomes. Journal of Business Venturing, v. 25, n. 1, p. 120-137, 2010.

JENSEN, M.C. Value maximization, stakeholder theory, and the corporate objective function. Business ethics quarterly, p. 235-256, 2002.

JONES, T. M.; WICKS, A.C. Convergent stakeholder theory. Academy of management review, v. 24, n. 2, p. 206-221, 1999.

LATOUR, B. Jamais fomos modernos. São Paulo: Editora 34, 1994.

MILES, S. Stakeholder theory classification: A theoretical and empirical evaluation of definitions. Journal of Business Ethics, v. 142, n. 3, p. 437-459, 2017.

NEVILLE, B. A.; MENGUC, B. Stakeholder multiplicity: Toward an understanding of the interactions between stakeholders. Journal of Business Ethics, v. 66, n. 4, p. 377-391, 2006.

PFEFFER, J.; SALANCIK, R.G. The external control of organizations: A resource dependence perspective. 1978.

PHILLIPS, R. Stakeholder legitimacy. Business ethics quarterly, v. 13, n. 1, p. 25-41, 2003.

PORTER, M. E. Competitive strategy: techniques for analysing industries and competitors. New York: Free Press, 1980.

POWELL, W. Neither markets nor hierarchy: network forms of organization. Res Organ Behav, 12, pp. 295-336. 1990.

PROVAN, K. G.; FISH, A.; SYDOW, J. Interorganizational networks at the network level: A review of the empirical literature on whole networks. Journal of Management, v. 33, n. 3, p. 479-516, 2007.

RIBEIRO, N. C.; ANTONIALLI, L. M.; ZAMBALDE, A. L. Análise sociométrica da estrutura da rede de propriedade intelectual de uma universidade pública. Perspectivas em Gestão \& Conhecimento, v. 5, n. 1, p. 127 146, 2015.

ROBERTS, N. C.; BRADLEY, R. T. Stakeholder collaboration and innovation: A study of public policy initiation at the state level. The Journal of Applied Behavioral Science, v. 27, n. 2, p. 209-227, 1991.
ROLOFF, J. A life cycle model of multi-stakeholder networks. Business Ethics: A European Review, v. 17, n. 3, p. 311-325, 2008.

ROTH, A. L. et al. Diferenças e inter-relações dos conceitos de governança e gestão de redes horizontais de empresas: contribuições para o campo de estudos. Revista de Administração, São Paulo, v. 47, n. 1, p. 112-123, 2012.

ROWLEY, T. J. Moving beyond dyadic ties: A network theory of stakeholder influences. Academy of Management Review, v. 22, n. 4, p. 887-910, 1997.

ROWLEY, T. J. The Power of and in Stakeholder Networks. In: WASIELESKI, D. M.; WEBER, J. (Eds). Stakeholder Management. Series Business and Society 360. Emerald Publishing Limited, 2017. p. 101-122.

ROWLEY, T. J.; MOLDOVEANU, M. When will stakeholder groups act? An interest-and identity-based model of stakeholder group mobilization. Academy of Management Review, v. 28, n. 2, p. 204-219, 2003.

RÜHLI, E. et al. Innovation in multistakeholder settings: The case of a wicked issue in health care. Journal of Business Ethics, v. 143, n. 2, p. 289-305, 2017.

SAUR-AMARAL, I. Revisão sistemática da literatura. Lisboa: Bubok, 2010.

SCARINGELLA, L.; RADZIWON, A. Innovation, entrepreneurial, knowledge, and business ecosystems: Old wine in new bottles? Technological Forecasting and Social Change, 2017. Available at: <https://doi. org/10.1016/j.techfore.2017.09.02>. Accessed on: Sept. 04, 2019.

SCHNEIDER, T.; SACHS, S. The impact of stakeholder identities on value creation in issue-based stakeholder networks. Journal of Business Ethics, v. 144, n. 1, p. 41-57, 2017.

SCIARELLI, M.; TANI, M. Network approach and stakeholder management. Business Systems Review, v. 2, n. 2, p. 175-190, 2013.

SCOTT, R.W.; DAVIS, G. F. Organizations and organizing: Rational, natural and open systems perspectives. New York: Routledge, 2017.

STOCKER, F.; MASCENA, K. M. C. Orientação e gestão para stakeholders no processo de decisão organizacional. Revista de Gestão e Secretariado, GESEC, São Paulo, v. 10, n. 1, p. 167-191, Jan./Apr. 2019.

TANTALO, C.; PRIEM, R. L. Value creation through stakeholder synergy. Strategic Management Journal, v. 37, n. 2, p. 314-329, 2016.

WADDOCK, S.A.; GRAVES, S.B. The corporate social performancefinancial performance link. Strategic management journal, v. 18, n. 4, p. 303-319, 1997.

VAN ECK, N. J.; WALTMAN, L. Visualizing bibliometric networks. In: DING. Y.; ROUSSEAU, R.; WOLFRAM, D. (Eds.). Measuring scholarly impact. Springer International Publishing, 2014. p. 285-320.

YANG, A.; BENTLEY, J. A balance theory approach to stakeholder network and apology strategy. Public Relations Review, v. 43, n. 2, p. 267-277, 2017.

ZACCARELLI, S. et al. Clusters e redes de negócios: uma nova visão para a gestão dos negócios. São Paulo: Atlas, 2008.

ZEDAN, S.; MILLER, W. Using social network analysis to identify stakeholders' influence on energy efficiency of housing. International Journal of Engineering Business Management, v. 9, p. 1-11, 2017.

ZENG, F. et al. Understanding distributor opportunism in a horizontal network. Industrial Marketing Management, v. 46, p. 171-182, 2015. 


\section{Fabricio Stocker}

ORCID: https://orcid.org/0000-0001-6340-9127

PhD Candidate in Business Administration at University of São Paulo - School of Economics, Business and Accounting (FEA-USP), São Paulo - SP, Brazil. E-mail: fabriciostocker@usp.br

Keysa Manuela Cunha de Mascena

ORCID: https://orcid.org/0000-0002-0844-500X

PhD in Business Administration at University of São Paulo - School of Economics, Business and Accounting (FEA-USP); Professor of the Graduate Program in Business Administration at the University of Fortaleza (PPGA-UNIFOR), Fortaleza - CE, Brazil. E-mail: keysamascena@unifor.br

\section{Ana Cláudia Azevedo}

ORCID: https://orcid.org/0000-0001-8141-9265

PhD in Business Administration at University of São Paulo - School of Economics, Business and Accounting (FEA-USP), São Paulo - SP, Brazil. E-mail: anacazevedo@usp.br

João Maurício Gama Boaventura

ORCID: https://orcid.org/0000-0003-3070-2153

PhD in Business Administration at University of São Paulo; Full Professor at the School of Economics, Business and Accounting, University of São Paulo (FEA-USP), São Paulo - SP, Brazil. E-mail: jboaventura@usp.br 